\title{
Quality of the Cutting Tool Microgeometry for Machining Aluminium Alloys
}

Ondřej Hronek, Miroslav Zetek, Tomáš Bakša, Pavel Adámek

Laboratory of Experimental Machining, Regional Technological Institute, Univerzitni 8, 30614 Pilsen, Czech Republic, E-mail: hroneko@rti.zcu.cz, mzetek@rti.zcu.cz, baksa@rti.zcu.cz, adamek@rti.zcu.cz

\begin{abstract}
Modern cutting tools with high quality attributes are very important factors for companies that want to increase their production efficiency and product quality. Cutting tool properties include high durability, endurance and cutting power. Quality shapes and surfaces of cutting edge micro and macrogeometry are also important. This article deals with cutting edge microgeometry on sintered carbide end mill tools. Drag finishing technology is used for preparation of cutting edge microgeometry. Two process media are used during the experiment. Due to the different process media, the final surface quality will also be different. Nowadays, cutting edge preparation is one of the basic but inseparable parts of development and production of cutting tools. Microgeometry quality affects the behaviour of cutting tools during the machining process. The behaviour mainly includes cutting forces, friction and vibration. The impacts of drag finishing on the functional surfaces of the cutting tool are investigated in this article. An IFM G4 microscope is used for measuring the cutting edge microgeometry.
\end{abstract}

Keywords: Cutting edge modification, Cutting edge microgeometry, Drag finishing, Surface quality

\section{Acknowledgement}

The present contribution has been prepared under project LO1502 'Development of the Regional Technological Institute' under the auspices of the National Sustainability Programme I of the Ministry of Education of the Czech Republic aimed at supporting research, experimental development and innovation.

\section{References}

[1] MÜLLER, M. (2017). Effects of Aluminium Microparticles and Surface Treatment of AlCu4Mg on Mechanical Properties of Adhesive Bond Strength. In: Manuffacturing Technology, Vol. 17, No. 1, pp. 66-71, ISSN 12132489

[2] PAPWORTH, A., FOX, P. (1997). The disruption of oxide defects within aluminium alloy castings by the addition of bismuth. In: Materials letters. Vol. 35, Issues 3 - 4, Pages 202 -206, ISSN $0167-577 \mathrm{X}$

[3] TIllovÁ, E., CHAluPOVÁ, M., KUCHARIKOVÁ, L., ZÁVODSKÁ, D., BELAN, J., VAŠKO, A. (2016). Use of Microscopy in the Study of Self-Hardening Al-Alloy for Automotive Application. In: Manuffacturing Technology, Vol. 16, No. 5, pp. 1085-1091, ISSN 1213 - 2489

[4] ŘIDKÝ, O., SOBOTKA, J. (2016). Influence of the Bending Momentum Loading of Testing Samples from the Alloy AlSi7Mg0,3 on the Surface Stress State Detected by X-ray Diffraction. In: Manuffacturing Technology, Vol. 16, No. 5, pp. 1123-1129, ISSN $1213-2489$

[5] NOVA, I., MACHUTA, J. (2016). Microstructure of Aluminium Alloys Casting Intended for Cyclical Thermal Stress In: Manuffacturing Technology, Vol. 16, No. 5, pp. 1174-1179, ISSN 1213 - 2489

[6] HRICOVA, J., NÁPRSTKOVÁ, N. (2015). Surface roughness optimization in milling aluminium alloy by using the Taguchis design of experiment. In: Manufacturing Technology, Vol. 15, No. 4, pp. 541-546. ISSN 12-132489

[7] DENKENA, B., KÖHLER, J., VENTURA, C.E.H. (2013). Customized cutting edge preparation by means of grinding. In: Precision Engineering. Vol. 37, Issue 3, Pages 590 - 598, ISSN 0141 - 6359

[8] RAZAVYKIA, A., FARAHANY, S., MOHD YUSOF, M. (2015). Evaluation of cutting force and surface roughness in the dry turning of Al-Mg2Si in-situ metal matrix composite inoculated with bismuth using DOE approach. In: Measurement. Vol. 76, Pages 170 - 182, ISSN 0263 - 2241

[9] ZETEK, M., BAKŠA, T., SCHORNÍK, V., ZETKOVÁ, I. (2016). Monitoring and Evaluating Cutting Tool Wear using a IFM G4 Microscope. In: Manufacturing Technology, Vol. 16, No. 5, pp. 1211-1216. ISSN 12-13 - 2489

[10] DENKENA, B., BIERMANN, D. (2014). Cutting edge geometries. In. CIRP Annals-Manufacturing Technology. Vol. 63, Issue 2, Pages $631-653$

[11] HRONEK, O., ZETEK, M., BAKŠA, T., ADÁMEK, P. (2016). Influences of Holders Speed on the Cutting Edge during Drag Finishing. In: In: Manuffacturing Technology, Vol. 16, No. 5, pp. 933-939, ISSN 1213 - 2489

[12] IBARAKI, S., SHIMIZU, T. (2010). A long-term control scheme of cutting forces to regulate tool life in end milling processes. In: Precision Engineering. Vol. 34, Issue 4, Pages 675 - 682, ISSN 0141 - 6359 